\title{
Ecological studies on the freshwater crayfish Procambarus clarkii in the Nile River at El-Mansoura city
}

\author{
Mansour Galal G.Y., Osman S. Khalefa and M. Maamoun \\ Zoo.Dept., Fac. of Sc., Menf. Univ., Shebin El-Koum.
}

\begin{abstract}
The present investigation proved that $P$. clarkii at less-polluted area recorded higher numerical densities and body weights than polluted ones. It was found that the minimal water temperature was more or less similar at less-polluted and polluted areas, while its maximal values were higher at polluted ones. This could be referred to the cumulative thermal effect of both weather and pollution. At the same time, the lower values of dissolved oxygen were similar $(5 \mathrm{mg} / \mathrm{L})$ at both examined areas, while the higher values showed a slight tendency towards less-polluted areas ( 8 and $7 \mathrm{mg} / \mathrm{L}$ at less-polluted and polluted regions, respectively). Data of the present study proved that river water near El-Semad factory was more alkaline than that near the electrical power station at Talkha. Simultaneously, ammonia levels were higher at the polluted areas $(0.13-0.55 \mathrm{mg} / \mathrm{L})$ as compared with those belonging to the lesspolluted area $(0.06-0.3 \mathrm{mg} / \mathrm{L})$.

Finally, it was exhibited that the reproductive capacity of $P$. clarkii in this study was higher than those of the other countries in the world particularly USA. This gives a good opportunity to rear this crustacean animal in a large scale to provide an efficient and cheap edible animal protein in Egypt. Therefore, China began to make a project near the River Nile in order to manufacture salty caned crayfish.
\end{abstract}

Key words : Crayfish, Numerical densities, P. clarkii.

\section{INTRODUCTION}

Procambarus clarkii have been introduced recently to Egypt in the early 1980's, when the first immigrants of this species were introduced from USA. The ecological surveys indicated that the crayfish had flourished and widely spread all over most of the River Nile and its tributaries (Ibrahim et al., 1995). P. clarkii usually live in marshes, rivers, slow flowing water, reservoirs, irrigation systems, and rice fields. It is an aggressive competitor and its burrowing behavior may cause significant agricultural problems (Ibrahim and Khalil, 2009).

According to Emam and Khalil (1995), P. clarkii is heavily exploited as a fishery product. They mentioned that the average annual yield of $P$. clarkia in Egypt achieved 4.6tones/ year. More extensive ecological and experimental studies on this crayfish were made in Egypt ( Emam and Mubarak,1999; Ibrahim et al., 2000; Emam, 2002 and Ibrahim et al., 2005). From the medical point of view, $P$. clarkii might serve in controlling certain human diseases caused by helminthes since it has shown to subsist on the vectors of such pathogens (Hunner \& Barr, 1991 and Hofkin et al., 1991).

\section{MATERIALS AND METHODS}

Weekly sampling during the study period (November 2009 to December 2010) was carried out at three different stations on the Nile River at EL Mansoura city, Dakahleyia province (study area of about $4 \mathrm{~km}$ length and 150 to 200 meter width). These stations 
represent a less-polluted area at EL Mashaia in the middle of the River, a polluted area near El-Mansoura fertilizer factory (EL Semad factory) and another polluted one connected to Talkha Electrical power station (Fig. 1). Numerical densities, weights and dimensions of the specimens belonging to ten catches per each location were tabulated. Simultaneously, water samples were collected in tightly closed clean glass vials from the same sampling regions to measure some physico-chemical parameters.

\section{RESULTS}

It was proved that the maximum number of Procambarus clarkii at less-polluted area achieved 640 animals on the second week of July, while that of polluted regions was 240 animals during the $4^{\text {th }}$ week of April (Fig. 2). On the other hand, the minimum number of $P$. clarkii at less polluted region was 60 animals on the $4^{\text {th }}$ week of January, while that of polluted area was 10 animals at the middle of November 2010.

Regarding the monthly numerical densities of total, male and female P. clarkia at various sampling regions, the maximal values were achieved during July and May at lesspolluted and polluted regions, while their minimal values were gained on December and January, respectively (Table 1). The size of males was larger than that of females and the range of body length (from rostrum to the end of telson) for both males and females was 9 $14 \mathrm{~cm}$ and $9-13.5 \mathrm{~cm}$, respectively. The length of the carapace from tip of rostrum to the posterior margin of the cephalothorax of both sexes varied between 4.6 and $7 \mathrm{~cm}$. The colour of the adults varied from deep red or reddish-brown to almost black with deep red sides, but that of young is greenish-brown

The relationship between the monthly total numerical density of $P$. clarkii and the studying period, using the regression analysis, was proved not statistically significant $(P>$ 0.05 ) at both less-polluted and polluted areas. The seasonal densities of this animal (Table 3 ) at less-polluted area ranged between 6920 on Summer and 1330 animals during Winter, while that of polluted regions varied from a maximum of 2460 on Spring and a minimum of 350 individuals on Autumn and these relations were proved not to be statistically significant $(\mathrm{P}>0.05)$.

Simultaneously, the relationship belonging to the numerical densities of male $P$. clarkii and the studying time was not statistically significant $(P>0.05)$ at both less-polluted and polluted regions. The seasonal variations of total male number varied between 4152 and 798 animals on Summer and Winter for less-polluted area, while those of polluted zones were 1476 on Spring and 210 animals during Autumn respectively.

On the other hand, the numerical density of female $P$. clarkii at less-polluted area fluctuated from 1136 to 148 individual during January and December, while those of the polluted areas declined from 360 to 56 animals on May and December. The relationship between those densities versus the studying time was proved not to be statistically significant $(P>0.05)$ at both less-polluted and polluted areas.

Simultaneously, seasonal female numbers exhibited 2768 and 532 animals as maximum and minimum values on Summer and Winter, while those of polluted regions varied between a maximum of 980 (Spring) and a minimum of 140 animals (Autumn).

Regarding the weight yield, it was proved that the maximum total weight was $32 \mathrm{~kg} / \mathrm{week}$ on July, while the minimum one achieved $3 \mathrm{~kg} /$ week during Dec. and Jan. at less-polluted area (Fig. 3). The maximal total weight was $12 \mathrm{~kg} /$ week by the end of April and the minimum one was $0.5 \mathrm{~kg} /$ week during November at both polluted areas. This relationship proved a statistically significant one $(P<0.05)$.

Dividing the whole data of the previously mentioned figure, it was found that the maximum weight of the ascending part of the curve at less polluted area achieved $32 \mathrm{~kg}$ during the second week of July, while that of the polluted regions was $12 \mathrm{~kg}$ in the fourth 


\section{Ecological studies on the freshwater crayfish Procambarus clarkii in the Nile River at El-Mansoura city}

week of April. On the other hand, the minimum weight of $P$. clarkii belonging to the ascending part at less-polluted and polluted areas was $3,1.5 \mathrm{~kg}$ in the fourth week of January respectively.

The maximal weight of the descending part at less-polluted and polluted areas was 28 and $9 \mathrm{~kg}$ in the $3^{\text {rd }}$ week of July, while the minimum weight of $P$. clarkii at less-polluted and polluted areas was $3 \mathrm{~kg}$ on December 2010 and $0.5 \mathrm{~kg}$ in the middle of November.

The monthly total weight of $P$ clarkii decreased from maximum value $(142 \mathrm{~kg})$ on July to minimum of $18.5 \mathrm{~kg}$ on Jan. 2009 for less-polluted area, while those of polluted area varied from a minimum of $7 \mathrm{~kg}$ on December to $45 \mathrm{~kg}$ maximally during May 2010 ( Table 2). Examining the relationship between body weights and the studying time was proved to be not statistically significant $(P>0.05)$ at both less-polluted and polluted regions.

The seasonal total weights (Table 3) of that crustacean animal varied between $66.5 \mathrm{~kg}$ during Winter and $346 \mathrm{~kg}$ on Summer at less-polluted area, while those of the polluted ones were 17.5 and $123 \mathrm{~kg}$ during Autumn and Spring respectively. Accordingly, the seasonal relationship of the weight of $P$. clarkii and the studying time was not statistically significant $(P>0.05)$ at both less-polluted and polluted areas.

It was found that the monthly weights of male $P$. clarkia declined from a maximum of $85.2 \mathrm{~kg}$ on July to a minimum of $11.1 \mathrm{~kg}$ on Jan. 2010 for less-polluted area, while those of the polluted regions declined from 27 to $4.2 \mathrm{~kg}$ during May and December respectively (Table 2). This relationship was proved to be not a statistically significant one $(P>0.05)$ at both less-polluted and polluted areas.

The seasonal weight yield for male $P$. clarkii varied between maximum of $207.6 \mathrm{~kg}$ during Summer and a minimum of $39.9 \mathrm{~kg}$ on Winter for less-polluted area, while those of polluted areas varied between 10.5 and $73.8 \mathrm{~kg}$ during Autumn and Spring respectively. It is necessary to mention that the relation between the seasonal total weights of males and the studying time was not statistically significant $(P>0.05)$ at less-polluted and polluted regions.

On the other hand, monthly weights of female $P$. clarkii fluctuated from a maximum of $56.8 \mathrm{~kg}$ during July to a minimum of $7.4 \mathrm{~kg}$ on Jan. 2010 at less-polluted area, while those at polluted area decreased from $18 \mathrm{~kg}$ to $2.8 \mathrm{~kg}$ on May and December. Accordingly, the seasonal variations of female weights ranged between 138.4 and $26.6 \mathrm{~kg}$ during summer and Winter for less-polluted areas, while those of polluted regions increased from 7 to $49.2 \mathrm{~kg}$ on Autumn and Spring. The relation between female body weights and the studying time was proved to be not statistically significant $(P>0.05)$ at both less-polluted and polluted areas.

It was found that the monthly water temperature (Table 4 ) at the less-polluted station (El-Mashaia) increased gradually from 18 to $30.2{ }^{\circ} \mathrm{C}$ on January and August 2010, while the polluted stations exhibited more obvious variations ( from 17 to $36.5^{\circ} \mathrm{C}$ on December and June 2010 at EL Semad station and from 22 to $41{ }^{\circ} \mathrm{C}$ during December and June 2010 at the Electrical power station). The relationship between water temperature and the studying time was proved to be statistically significant $(P<0.05)$ at less-polluted area, while those of EL Semad and the Electrical power stations were not statistically significant $(P>0.05)$.

Minimal and maximal values of dissolved oxygen at less-polluted station were 5 and $8 \mathrm{mg} / \mathrm{L}$ during October and September 2010, while those of polluted stations achieved 5 $\mathrm{mg} / \mathrm{L}$ at Electricity station and $7 \mathrm{mg} / \mathrm{L}$ at EL Semad factory station (Table 4). The relationships between dissolved oxygen and the studying time (monthly and seasonally) were proved to be not statistically significant $(P>0.05)$ at less-polluted and polluted areas.

The $\mathrm{pH}$ of the water samples belonging to the different regions was mostly alkaline as could be seen in Table (4). The monthly values of $\mathrm{pH}$ at the less-polluted station ranged from 7.53 to 7.8 on August and December respectively, while those of both polluted stations varied from 7.05 to 8.3 during April near by Electricity station and on November at EL 
Semad factory station. This relationship was proved to be statistically significant $(P<0.05)$. Simultaneously, the seasonal levels fluctuated between 7.59 on summer and 7.74 during Spring at less-polluted station, while those of polluted ones changed from 7.47 on Spring at Electricity station to 7.93 on Autumn at EL Semad station and this relation was not statistically significant $(P>0.05)$.

The monthly levels of ammonia were changed from 0.06 to $0.3 \mathrm{mg} / \mathrm{l}$ on October and February, from 0.13 to $0.5 \mathrm{mg} / \mathrm{l}$ during April and July and from 0.2 to $0.6 \mathrm{mg} / \mathrm{l}$ on April and July at less polluted, El-semad and Electricity sampling stations respectively. This relationship was proved to be significant $(\mathrm{P}<0.05)$ at less polluted station and insignificant $(\mathrm{P}>0.05)$ at both polluted ones.

\section{DISCUSSION}

It is worthy to keep in mind that data of male, female plus their ascending and descending parts of both weekly numerical densities and body weights of this crustacean animal are statistically significant with the studying time $(0.05>\mathrm{P}<0.001)$ at both lesspolluted and polluted areas.

Comparing the present data with others indicated that $P$. clarkii have different body colour, length and size in adults and youngsters. Huner and Romaire (1978) found that body size was directly influenced by habitat quality. Total body length of $P$. clarkii changed from place to anther. In Egypt a range varied from $4.4 \mathrm{~cm}$ to $12.4 \mathrm{~cm}$ for adult (Mubarak; 2001), but in Louisiana total length did not exceed $11.6 \mathrm{~cm}$ and 47 gram body weight (Penn, 1943), $P$. clarkii in pond near Zurich (Switzertand) was $10.05 \mathrm{~cm}$ and its life span was 3 years (Frutiger et al., 1999).

Sex ratio in the present study proved that the numerical density of male is more than that of females (1.5:1), while that of Frutiger et al. (1999) was 1.33: 1.0. The highest mortality $(90 \%)$ occurred when all individuals were belonging to the same sex due to their aggressive behavior (Raafat, 2006). It was found that size of male was larger than that of female for two reasons; the lower frequency of moulting and the feeding inhibition in females during the studying period (Skurdal and Qvenlid, 1986; Pursiainen et al., 1987). Simultaneously, $P$. clarkii in the present study have two generations per year; the first generation was obtained during April and early May and the second happened on late September and October, while that in southern United States have one generation per year in early summer (Huner and Barr, (1991). This means that reproductive capacity for $P$. clarkii is very high in the Egyptian water (Soliman et al., 1998 b). This crayfish began the active season on late March when the temperature increases and the water level in different channels and ditches raised up after the winter closure period (Mubarak, 1996). Accordingly, water temperature accounts as one of the main factors that affect on life, growth, metabolic activity, food intake and reproduction for P. clarkii. At less-polluted area the water temperature had normal range $\left(18{ }^{\circ} \mathrm{C}\right.$ to $\left.30.2{ }^{\circ} \mathrm{C}\right)$ but the polluted area had abnormal range of water temperature especially near the electrical power station where its values varied between $22{ }^{\circ} \mathrm{C}$ and $41{ }^{\circ} \mathrm{C}$, while those near EL Semad factory changed from $17^{\circ} \mathrm{C}$ to $36{ }^{\circ} \mathrm{C}$. Espina et al. (1993) found that $P$. clarkii preferred temperature at $23.4^{\circ} \mathrm{C}$, while a temperature range of 20 $-29^{\circ} \mathrm{C}$ had no effect on the developmental stages or the acclimation for P. clarkii. Habashy (2004) reported that, the relation between temperature and growth rate of P. clarkii in Egypt was significant $(\mathrm{P}<0.05)$ and the growth rate varied at different temperature levels $(15,20$, 25 and $\left.30{ }^{\circ} \mathrm{C}\right)$. He proved also that growth at higher temperature $\left(30{ }^{\circ} \mathrm{C}\right)$ was almost three times greater than that at lowest temperature. Jussila and Evans, (1996) reported that growth rate was higher at optimum temperature and decreased when water temperature deviated from the optimum one. Peck (1985) mentioned that as water temperature affected the solubility of oxygen and many other factors in water, it influenced the abundance of the crayfish at various habitats. Mickie et al, (2006) proved that high temperature $\left(35^{\circ} \mathrm{C}\right)$ lead to a decreased 


\section{Ecological studies on the freshwater crayfish Procambarus clarkii in the Nile River at El-Mansoura city}

metabolic rate. Low temperature acclimation $\left(10{ }^{\circ} \mathrm{C}\right)$ resulted in $20 \%$ mortality in P. clarkii, while acclimations at $30{ }^{\circ} \mathrm{C}$ did not have any effect on the metabolic rate. Ackefors, (1999) reported that, in Lake Trasimeno optimal temperature was $21-27^{\circ} \mathrm{C}$ and growth inhibition occurred at temperatures below $12^{\circ} \mathrm{C}$.

Ibrahim et al. (2000) found that water temperature affected growth of $P$. clarkii by its influence on moulting interval; when temperature changed from 18 to $30{ }^{\circ} \mathrm{C}$ the moulting time interval decreased from 63.2to 21.4 days for mature and from 26.6 to11.6 days for immature animal. Huner (1988) reported that moulting rates increase in temperatures between 22 to $30{ }^{\circ} \mathrm{C}$. Hartnoll (1983) mentioned that temperature and food supply affected the intermoult duration. Kumlu et al. ( 2000) reported that high temperature at certain point increased the moulting frequency and consequently growth. Soliman, et al. (1998) suggested that mating activity of $P$. clarkii was present all the year round, but increased in May. Females kept sperms in its seminal receptacle for about 2-8 months until time of fertilization. Richardson et al. (2007) observed that the ovarian development in mature females of this animal was temperature dependent. It was reported that temperature affected the period of egg hatching which usually last about 3 weeks (Gherardi, 2002). Simultaneously, Soliman, et al. (1998) found that the period of embryonic development usually spent about 10 to 20 days, depending on water temperature as well. Ibrahim et al. (2006) found that, in Egypt, temperature and photoperiod influenced egg laying in P.clarkii. Also, when temperature exceeds $30{ }^{\circ} \mathrm{C}$ it caused high morality, lower percentage of ovigerous female and increasing the time of egg laying. At $27{ }^{\circ} \mathrm{C}$, P.clarkii took short time to egg laying and highest percentage of ovigerous at $29{ }^{\circ} \mathrm{C}$.

France (1984 and 1985) and Berrill et al. (1985) showed that crayfish could tolerate high range of $\mathrm{pH} 6.5$ to 8.5, while Ibrahim et al. (2006) found that the water $\mathrm{pH}$ should range from 6.5 to 7.5. France (1984) mentioned that low $\mathrm{pH}(<5.5)$ could result in eventual population extinction due to mortality of juveniles. Jensen and Malte (1990) ; Ellis and Morris (1995) reported that $P$. clarkii could tolerate $\mathrm{pH} 2$ for 24 hour which caused $100 \%$ mortality but $\mathrm{pH} 3$ caused 50\% mortality in four days, while McMahon and Stuart (1989) proved that $P$. clarkii could tolerate $\mathrm{pH} 4$ for 60 days.

Dissolved oxygen is a basic requirement needed for healthy crustacean, but $P$. clarkii can depend on atmospheric oxygen to meet its oxygen needs by moving to more highly oxygenated water or by turning on their sides at the water surface in order to utilize atmospheric oxygen (Penn 1943, Konikoff 1977, Huner and Barr 1984). It was found that the dissolved oxygen at the less-polluted area ranged from 5 to $8 \mathrm{mg} / \mathrm{l}$, while at polluted area it ranged from 5 to $7 \mathrm{mg} / \mathrm{l}$ (El-Semd factory) and from 5 to $6.2 \mathrm{mg} / \mathrm{l}$ near Talkha station. Moreover, Hobbs (1975) and Huner and Lindqvist (1995) mentioned that crayfish can adapt itself by increasing its gill filament surface and hence use the atmospheric oxygen. Vander (2003) mentioned that crustaceans could suffer from suffocation when dissolved oxygen concentrations declined to 3-4 $\mathrm{mg} / \mathrm{L}$.

Ammonia is toxic to a variety of aquatic organisms including fish (Harris et al. 1998). Also un-ionized form of ammonia account the most toxic form to aquatic organisms because it can readily diffuse through cell membranes, highly soluble in liquids causing impairment of cerebral energy metabolism and damaging gill, liver, kidney, spleen and thyroid tissue in fish, crustaceans and molluscs. (Smart, 1978). Reid (1961) reported that the concentration of ammonia $(1 \mathrm{mg} / \mathrm{l})$ has been given as an indicator of organic pollution and ammonia is toxic in concentration over $2.5 \mathrm{mg} / \mathrm{l}$ to aquatic organism. Simultaneously, the severe biological effect of nitrite on crustacean species was indicated by Rouse and Yeh (1995), since under the effect of nitrite, crustacean haemocyanin changes to methoglobin causing hypoxia and cyanosis. 


\section{REFERENCES}

Ackefors, H. (1999): The positive effects of established crayfish introductions in Europe. In: Gherardi .F. and Holdichd D.M., (eds). Crayfish in Europe as Alien Species (How to make the best of a bad situation?). Crustacean issuses, 11, A.A. Balkema, Rotterdam, Nethrlands, ,49-62.

Berrill, M., L.; Hollett, A. M. and J. Hudson. (1985): Variation in tolerance to low environmental $\mathrm{pH}$ by the crayfish Qrconectes rusticus. O. propinqiius. And Cambarus robustus. Can. J. Zool., 63:2586-2589.

Brown. D. J. A and Brown. J. A) Society for Experimental Biology Seminar Series., 34:171199.

Ellis, B.A. and Morris, S. (1995): Effects of extreme pH on the physiology of Australian yabbie chera destructor. Acute and chronic changes in heamolymph carbon dioxide, acid- base and ionic status. J. Exp. Biol., 198:395-407.

Emam, W. M.(2002). Stock assessment of the newly introduced crayfish Procambarus clarkii in El-Menoufia governorate, Egypt. J.Egypt. Acad. Soc. Environ. Develop. (D- Environmental Studies), 3(1): 1-19.

Emam, W. M. and Khalil, M. T. (1995): Population dynamics and stock assessment of the newly introduced crayfish, P. clarkii in the River Nile, Egypt. Proc. Zool. Soc.

A.R. Egypt, 26: 131-143.

Emam, W.M. and Mubarak, F. M. (1999). Field study on types of traps and some factors affecting trap catchability of the crayfish Proacmbarus clarkii in Egypt. Egyptian J. Aquatic Biology \& Fisheries, 3(4): 269-295.

Espina, S.; Herrera, F.Z. and L.Fernando, B. R. (1993): Preferred and avoided temperatures in the crawfish Procambarus clarkii (Decapoda, Cambaridae).

J. Therm. Biol., 18(1) : 35-39.

France, R.L. (1984): Comparative tolerance to low pH of three life stages of the crayfish Qrconectes virilis. Can. J. Zool., 62:2360-2363.

France, R. L. (1985): Low pH avoidance by crayfish (Qrconectes viriljs): evidence for sensory conditioning. Can. J. Zool., 63:258-262.

Frutiger, A.; Borner, S. and Busser, T. (1999): How to control unwanted population of Procambarus clarkii in Central Europe? Freshwater Crayfish., 12: 714-726.

Gherardi, F. G. (2002): Behavior. In: Biology of Freshwater crayfish. Blackwell Scientific publishing, Oxford, UK. (ed. By Holdich)., pp: 258-290.

Habashy, M.M. (2004): Survival and growth rates of procambarus clarkii, Girard (Crastacea, Decapoda) under different temperature and salinity levels. J. Egypt Ger. Soc. of Zool., (43 D): 135 - 146.

Harris, J.O., G. B. Maguire, S. Edwards and S. M. Hindrum. (1998). Effect of ammonia on the growth rate and oxygen consumption of juvenile greenlip abalone, Haliotis laevigata Donovan. Aquaculture., 160: 259-272.

Hartnoll, R.G. (1983): Strategies of crustacean growth: from the Conference on the Biology and Evolution of crustaceans (eds J.K. lowery)., pp.121-131.

Hobbs, H. H. Jr. (1975): Adaptation and convergence in North American crayfishes. Freshwater Crayfish, 2: 541-552.

Hofkin, B.V.; Mkoji, G.M.; Koech, D.K. and Loker, E.S. (1991). Control of schistosometransmitting snails in Kenya by the North American crayfish Procambarus clarkii. Am. J. Trop. Med. Hyg., 45 (3) 339-344.

Huner, J.V. (1988): Procambarus in North America and elsewhere. In: Freshwater Crayfish: Biology, Management and Exploitation (eds), (Holdich. D.M. and Lowery. R.S. Chapman and Hall, London., 239-261. 


\section{Ecological studies on the freshwater crayfish Procambarus clarkii in the Nile River at El-Mansoura city}

Huner, J.V. and Barr, J. E. (1991): Red swamp crawfish .Biology and exploitation. $3^{\text {rd }}$ edition, Louisiana Sea Grant College Program. Louisiana State University, Baton Rouge, Louisiana, USA.

Huner, J. V. and Lindqvist, O.V. (1998): Physiological adaptations of freshwater crayfishes that permit successful aquaculture enterprises. American Zoologist., 35: 12-19.

Huner J.V.; Romaire, R.P. (1978): Size at maturity as a means of comparing populations of Procambarus clarkii (Girard) (Crustacea, Decapoda) from different habitats. Freshwater Crayfish., 4:53-64.

Ibrahim, A.M.; Emam, W.M.and Abd El-Rahman, A.S. (2005). Ridding of undesirable crayfish Procambarus clarkii from certain habitats in Egypt by means of an organophosphorus insecticide. J. Egypt. Acad. Soc. Environ. Develop., (D-Environmental Studies), 6(2): 267-276.

Ibrahim, A. M.; Emam, W. M.; Beltagy, S. M.; Tharwat, A. A.; and Mubarak, F. M.(2000): On some factors affecting molting of the crayfish Procambarus clarkii from the River Nile, Egypt. J. Environ. Sci., 1(1):23-45.

Ibrahim, A. M.; Emam, W .M.; Fakhry, F. M.; Rifai, A. and Abd-El Rahman, A. S. (2006): Toxicity and bioaccumulation of some heavy metals in the crayfish Procambarus clarkii from the River Nile, Egypt. J. Egypt. Acad. Soc. Environ. Develop. (DEnvironment Studies)., 7(2): 131-158.

Ibrahim, A. M.; Khalil, M.T. and Mubarak, M.F. (1995). On the feeding behavior of the exotic crayfish Procambarus clarkia, in Egypt and its prospects in biocontrol of local vector snails. J. Union Arab. Biol.Zool., 4(A): 321-340.

Ibrahim, A. M. and Khalil, M.T. (2009). The Red Swamp Crayfish in Egypt. (A fast spreading freshwater invasive crustacean).

Ain-Shams Publication Center of Research and Protectorates, Egypt.

Jensen, F. and Malte, H. (1990): Acid- base and electrolyte regulation and heamolymph gas transport in crayfish Astacus astacus exposed to soft acid water with and without aluminum. J. Com. physiol., 160(B):483-490.

Jussila, J. and Evans, L. H. (1996): On the factors affecting marron, Cherax tenuimanus, growth in intensive culture. Freshwater Crayfish., 11:428-40.

Konikoff, M. (1977): Study of the life history and ecology of the red swamp crawfish, Procambarus clarkii, in the lower Atchafalaya Basin floodway. Final Report. U.S. Fish and Wildlife Service, Univ. of Southwestern Louisiana., pp. 81.

Kumlu, M.; Eroldogan, O. T. and Aktas, m. (2000): Effect of temperature and salinity on larval growth, survival and development of Penaeus semisulcatus. Aquaculture., 188: $167-173$.

McMahon, B. R. and Stuart, S. A. (1989): Physiological problems of crayfish in acid waters. In: Acid toxicity and Aquatic Animals, (eds. Morris. R, Taylor. E. W,

Mickie, L. P. and Stephen, A. W. (2006): Effect of temperature acclimation on metabolism and hemocyanin binding affinities in two crayfish, Procambarus clarkii and Procambarus zonangulus Comparative Biochemistry and Physiology - Part A: Molecular \& Integrative Physiology., 144( 2): 211-217.

Mubarak, M. F. (1996): Ecological studies on the newly introduced freshwater cray- fish, $P$. clarkii and its impact upon the diversity of zooplankton and bottom fauna in the River Nile, Egypt. MSc. Thesis, Institute of Environmental Studies and Researches, Ain Shams University. pp .120. 
Mubarak, M.F. (2001): Fishery management of the exotic crayfish, Procambarus clarkii in the irrigation canal system of the River Nile, Egypt. Ph.D. Thesis, Institute of Environmental Studies and Researches, Ain Shams University.

Peck, S. K. (1985): Effects of aggressive interaction on temperature selection by the crayfish, Orconectes virilis. Amer. Midi. Nat., 114(1):159-167.

Penn, G.H. (1943): A story of the life history of the Louisiana crayfish Procambarus clarkii (Girard). Ecology., 24 (1): 1-18.

Pursiainen, M.; Saarela, M. and Westman, K. (1987): Moulting and growth of the noble crayfish, Astcus astacus in an oligotrophic lake. Freshwater crayfish.,7:155-164.

Raafat, H. A. (2006): Biological and physiological studies on the freshwater crayfish Procambarus clarkii. Ph. D. Thesis, Department of Zoology, Girls College for Arts, Science and Education Ain Shams University., pp.267.

Reid, K. G., (1961): Ecology of inland waters and estuaries. Texbook UNR, New York., pp:357.

Richardson, W. B.; Boethel, D. and Coreil, P. D. (2007): Louisiana Crawfish Production Manual. Louisiana State University Center. Pub2637. Ag Center Researh Extention., pp. 60 .

Rouse, D. B. and Yeh, H. S. (1995): Factors influencing spawning of Cherax quadrinatus in indoor hatcheries. Freshwater. Crayfish., 10: 605-610 .

Skurdal, J. and Qvenild, T. (1986): Growth, maturity and fecundity of Astcus astacus in Lake Steinsfjordin, (eds )Norway. S.E. Freshwater Crayfish., 6:182-186.

Smart , G. R. (1978): Investigations on the toxic mechanisms of ammonia to fish - gas exchange in rainbow trout (Salmo gairdneri) exposed to acutely lethal concentrations. J. Fish Biol., 12 : 93 - 104.

Soliman, G. N.; EL-Assal, F.; Salah EL-Deen, M. and Hamdy, S. A .H. (1998b): The reproductive biology of the red swamp crayfish procambarus clarkii (Girard, 1852)(Decapoda: Cambaridae) in the River Nile, Egypt. Egypt. J. Zool., 30 : 311 325.

Vander, O. (2003): Bioaccumulation and biomarkers in environmental risk assessment: a review, Environ. Toxicol. Pharmacol., 13: 57- 149. 
Ecological studies on the freshwater crayfish Procambarus clarkii in the Nile River at El-Mansoura city
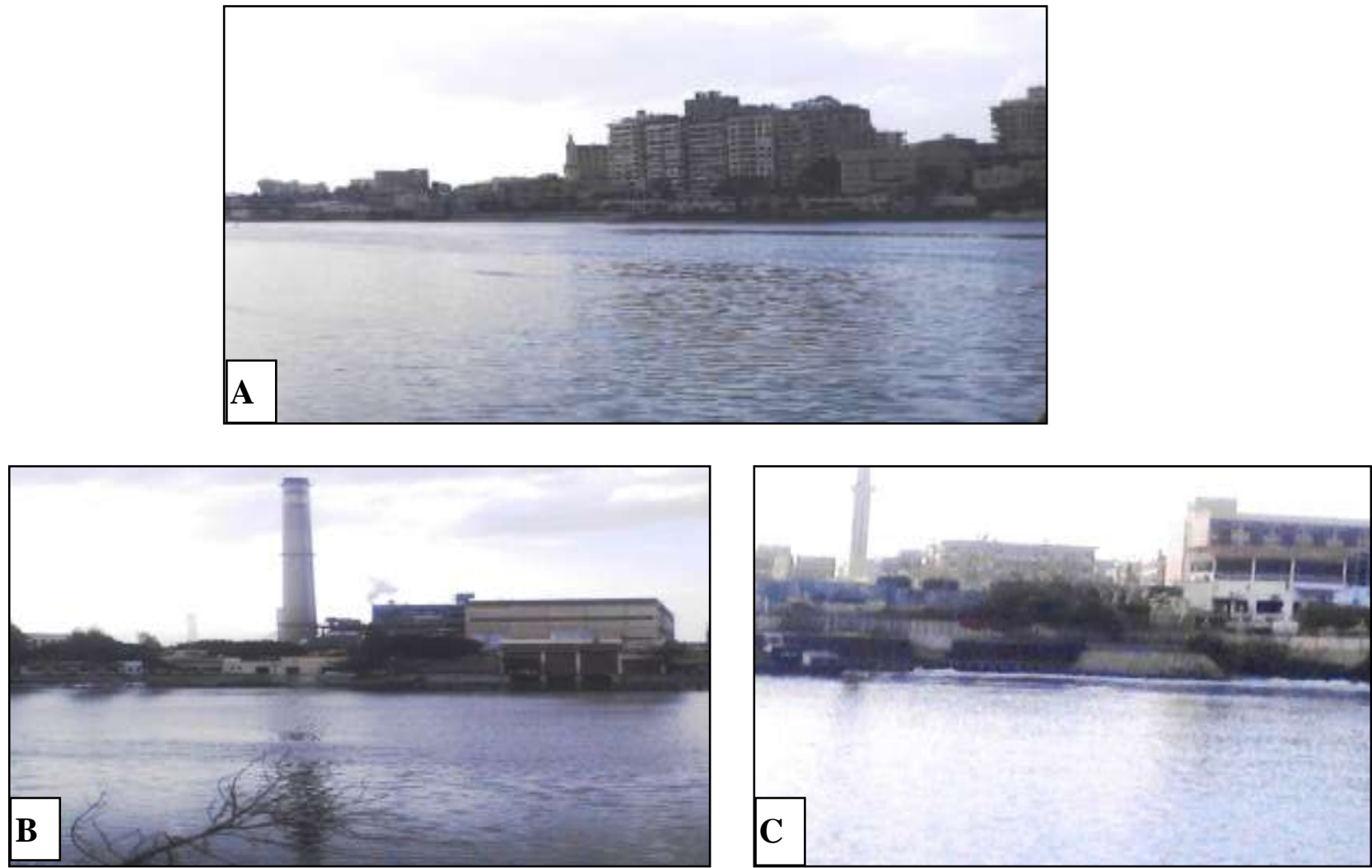

Fig. (1). Sampling stations at less-polluted and polluted regions at El-Mansoura city. A Less-polluted area at El-Mashaia

B - Chemically polluted region at El-Semad factory

C - Thermally polluted area at Talkha

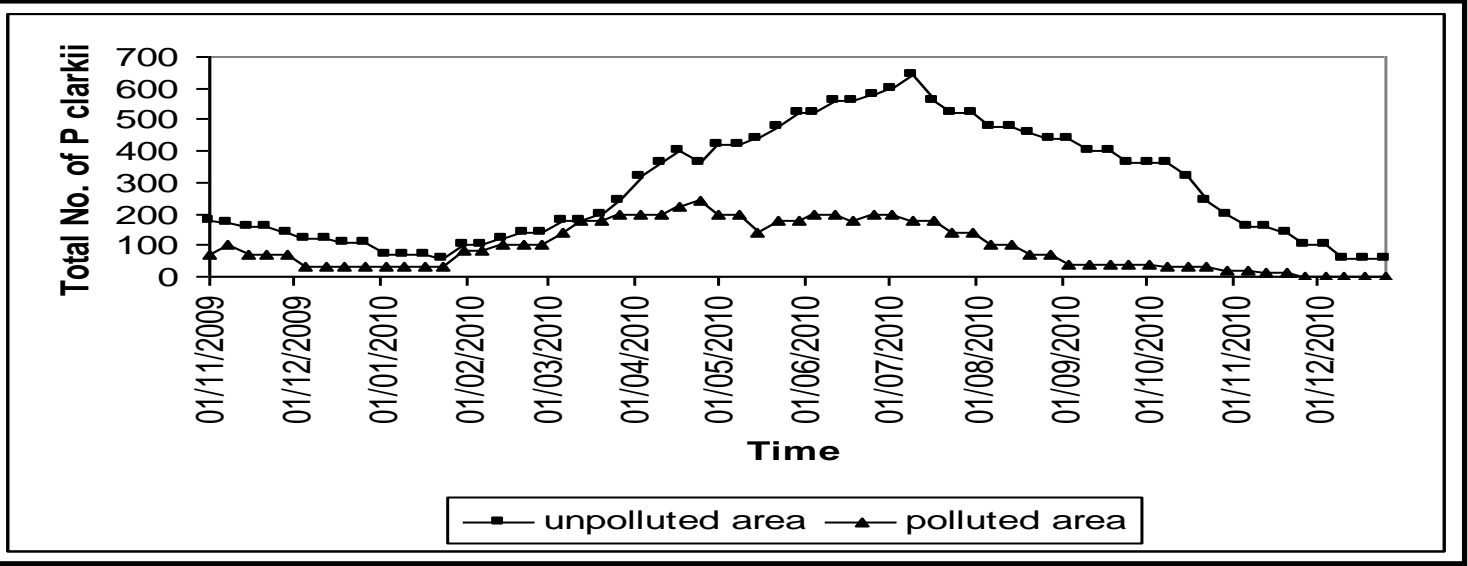

Fig. (2) : Weekly numerical density of $P$. clarkii from polluted and

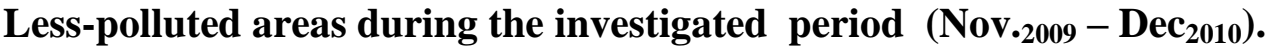


Mansour Galal G.Y. et al.

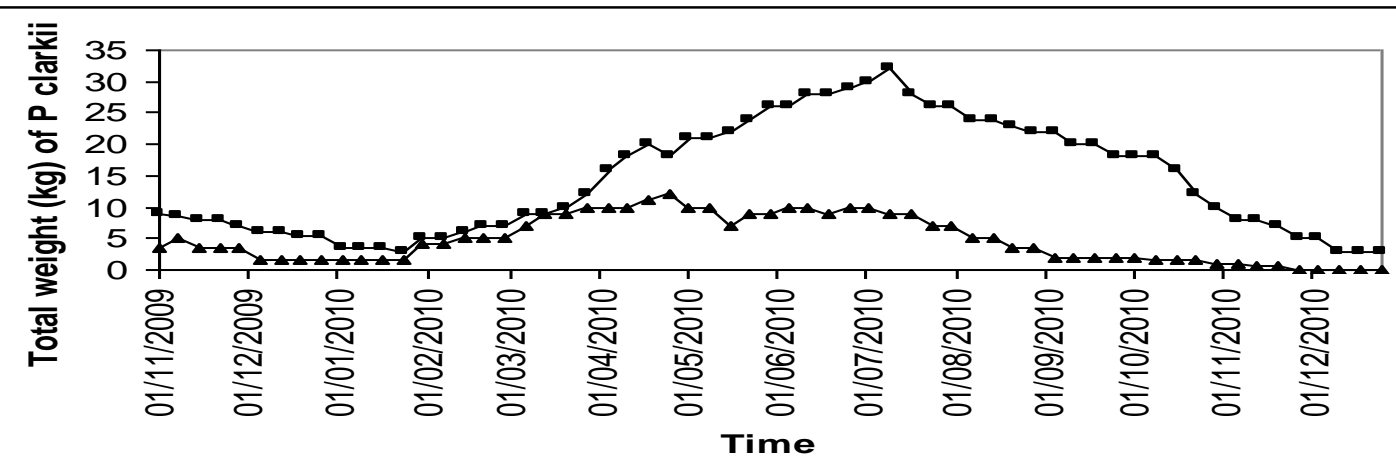

- unpolluted area $\_$polluted area

Fig. (3): Weekly variations of total weight (kg) of $P$. clarkii from polluted and lesspolluted areas during the studying period.

Table (1) Monthly numerical densities of male, female and total of $P$. clarkii at lesspolluted and polluted areas during the present study.

\begin{tabular}{|c|c|c|c|c|c|c|c|c|c|c|c|c|c|c|}
\hline $\begin{array}{l}\text { Month } \\
\text { Areg }\end{array}$ & $\begin{array}{l}\text { Nov. } \\
\text { Dec. } \\
2009\end{array}$ & $\begin{array}{l}\text { Jan. } \\
2010\end{array}$ & Feb. & Mar. & Apr. & May. & Jun. & Jul. & Aug. & Sep. & Oct. & Nov. & Dec. \\
\hline $\begin{array}{c}\text { Less-polluted } \\
\text { Total no. }\end{array}$ & 810 & 460 & 370 & 500 & 800 & 1440 & 2280 & 2220 & 2840 & 1860 & 1600 & 1480 & 560 & 280 \\
\hline Male no. & 486 & 276 & 222 & 300 & 480 & 864 & 1368 & 1332 & 1704 & 1116 & 960 & 888 & 336 & 168 \\
\hline Female no. & 324 & 184 & 148 & 200 & 320 & 576 & 912 & 888 & 1136 & 744 & 640 & 592 & 224 & 112 \\
\hline Polluted & 380 & 140 & 205 & 380 & 700 & 860 & 900 & 780 & 840 & 340 & 160 & 150 & 40 & 0 \\
\hline Total no. & 228 & 84 & 123 & 228 & 420 & 516 & 540 & 468 & 504 & 204 & 96 & 90 & 24 & 0 \\
\hline Male no. & 152 & 56 & 82 & 152 & 280 & 344 & 360 & 312 & 336 & 136 & 64 & 60 & 16 & 0 \\
\hline Female no. & & & & & & & & & & & \\
\hline
\end{tabular}

Table (2): Monthly body weights of male, female and total of $P$. clarkii (Kg) at lesspolluted and $p$ olluted areas during the present study.

\begin{tabular}{|c|c|c|c|c|c|c|c|c|c|c|c|c|c|c|}
\hline Month & $\begin{array}{l}\text { Nov. } \\
2009\end{array}$ & Dec & $\begin{array}{l}\text { Jan. } \\
2010\end{array}$ & Feb. & Mar & Apr. & $\begin{array}{c}\text { May } \\
\cdot\end{array}$ & Jun. & Jul. & Aug. & Sep. & Oct. & Nov. & Dec. \\
\hline$\frac{\text { Less-polluted }}{\text { Total wt. }}$ & 40.5 & 23 & 18.5 & 25 & 40 & 72 & 114 & 111 & 142 & 93 & 80 & 74 & 28 & 14 \\
\hline Male wt. & 24.3 & 13.8 & 11.1 & 15 & 24 & 43.2 & 68.4 & 66.6 & 85.2 & 55.8 & 48 & 44.4 & 16.8 & 8.4 \\
\hline Female wt. & 16.2 & 9.2 & 7.4 & 10 & 16 & 28.8 & 45.6 & 44.4 & 56.8 & 37.2 & 32 & 29.6 & 11.2 & 5.6 \\
\hline$\frac{\text { Polluted }}{\text { Total wt. }}$ & 19 & 7 & 10.25 & 19 & 35 & 43 & 45 & 39 & 42 & 17 & 8 & 7.5 & 2 & $\mathbf{0}$ \\
\hline Male wt. & 11.4 & 4.2 & 6.15 & 11.4 & 21 & 25.8 & 27 & 23.4 & 25.2 & 10.2 & 4.8 & 4.5 & 1.2 & $\mathbf{0}$ \\
\hline Femle wt. & 7.6 & 2.8 & 4.1 & 7.6 & 14 & 17.2 & 18 & 15.6 & 16.8 & 6.8 & 3.2 & 3 & 0.8 & 0 \\
\hline
\end{tabular}


Table (3) Seasonal variations of the numerical densities and body weights of $\boldsymbol{P}$. clarkii at less-polluted and polluted regions during the present study.

Numerical densities

Body weights

\begin{tabular}{|l|l|l|l|l|l|l|l|l|l|}
\hline $\begin{array}{l}\text { Seasons } \\
\text { Areas }\end{array}$ & Win. & Spr. & Sum. & Aut. & Win. & Spr. & Sum. & Aut. \\
\hline $\begin{array}{l}\text { Less- } \\
\text { polluted } \\
\text { Total no. }\end{array}$ & 1330 & 4520 & 6920 & 3640 & 66.5 & 226 & 346 & 182 \\
\hline Male no. & 798 & 2712 & 4152 & 2184 & 39.9 & 135.6 & 207.6 & 109.2 \\
\hline Female no. & 532 & 1808 & 2768 & 1456 & 26.6 & 90.4 & 138.4 & 72.8 \\
\hline $\begin{array}{l}\text { Polluted } \\
\text { Total no. }\end{array}$ & 725 & 2460 & 1960 & 350 & 36.25 & 123 & 98 & 17.5 \\
\hline Male no. & 435 & 1476 & 1176 & 210 & 21.75 & 73.8 & 58.8 & 10.5 \\
\hline Female no. & 290 & 980 & 784 & 140 & 14.5 & 49.2 & 39.2 & 7 \\
\hline
\end{tabular}

Table (4) Measurements of certain physico-chemical parameters at less-polluted and polluted areas of the Nile sector in El-Mansoura city.

\begin{tabular}{|c|c|c|c|c|c|c|c|c|c|c|c|c|c|c|}
\hline Months & $\begin{array}{c}\text { Nov. } \\
2009\end{array}$ & Dec. & $\begin{array}{c}\text { Jan. } \\
2010\end{array}$ & Feb. & Mar. & Apr. & May & Jun. & Jul. & Aug. & Sep. & Oct. & Nov. & Dec. \\
\hline $\begin{array}{c}\text { ELMashia station } \\
\text { (Control area) }\end{array}$ & 21.4 & 19.1 & 18 & 18.7 & 20.5 & 24.5 & 26.5 & 27 & 28 & 30.2 & 27.5 & 27.2 & 25 & 22 \\
\hline $\begin{array}{c}\text { EL Semad station } \\
\text { (Polluted area) }\end{array}$ & 21 & 21 & 18.2 & 22.9 & 19.8 & 26.7 & 26.5 & 36.5 & 31.2 & 35 & 32 & 25 & 22.5 & 17 \\
\hline $\begin{array}{c}\text { Electricity station } \\
\text { (Polluted area) }\end{array}$ & 25.5 & 26 & 22.4 & 26.1 & 24.6 & 33.1 & 31.2 & 41 & 36 & 40 & 37.2 & 29 & 27 & 22 \\
\hline
\end{tabular}

\begin{tabular}{|l|c|l|c|c|c|c|c|c|c|c|c|c|c|c|}
\hline ELMashia st. & 6 & 6 & 6 & 5.7 & 6.1 & 5.9 & 7.3 & 5.8 & 5.3 & 5.2 & 8 & 5 & 6 & 6.8 \\
\hline EL Semad st. & 5.5 & 5.4 & 5.8 & 7 & 5.5 & 6 & 6.1 & 6.4 & 5.5 & 5.3 & 5.5 & 5.9 & 5.4 & 6 \\
\hline Electricity st. & 5 & 5.1 & 5.4 & 6.2 & 5 & 5.7 & 5.6 & 5.9 & 5 & 5.1 & 5.3 & 5.5 & 5 & 5.5 \\
\hline
\end{tabular}

\begin{tabular}{|c|c|c|c|c|c|c|c|c|c|c|c|c|c|c|}
\hline \multicolumn{15}{|c|}{ 3- $\mathrm{pH}$} \\
\hline ELMashia st. & 7.75 & 7.8 & 7.7 & 7.7 & 7.7 & 7.72 & 7.8 & 7.61 & 7.62 & 7.53 & 7.6 & 7.57 & 7.74 & 7.65 \\
\hline EL Semad st. & 8.3 & 7.9 & 7.75 & 7.79 & 7.85 & 7.3 & 7.8 & 7.9 & 7.7 & $\overline{8}$ & 8.1 & 7.8 & 7.89 & 7.9 \\
\hline Electricity st. & 8.27 & 7.85 & 7.8 & 7.7 & 7.6 & 7.05 & 7.75 & 7.8 & 7.6 & 7.95 & 8 & 7.7 & 7.8 & 7.8 \\
\hline
\end{tabular}

4-Amonia

\begin{tabular}{|l|c|c|c|c|c|c|c|c|c|c|c|c|c|c|}
\hline ELMashia st. & 0.2 & 0.17 & 0.19 & 0.3 & 0.21 & 0.15 & 0.1 & 0.16 & 0.2 & 0.14 & 0.1 & 0.06 & 0.19 & 0.12 \\
\hline EL Semad st. & 0.29 & 0.35 & 0.21 & 0.38 & 0.25 & 0.13 & 0.32 & 0.35 & 0.5 & 0.3 & 0.27 & 0.38 & 0.4 & 0.33 \\
\hline Electricity st. & 0.39 & 0.46 & 0.35 & 0.55 & 0.38 & 0.2 & 0.41 & 0.52 & 0.6 & 0.4 & 0.32 & 0.45 & 0.48 & 0.39 \\
\hline
\end{tabular}


دراسات بيئية على استاكوزا الماء العذب بروكامبرس كلاركى فى نهر النيل بمدينة المنصورة

منصور جلال- جمالات عثمان- شيرين خليفةـ منى مأمون

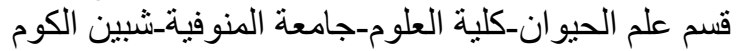

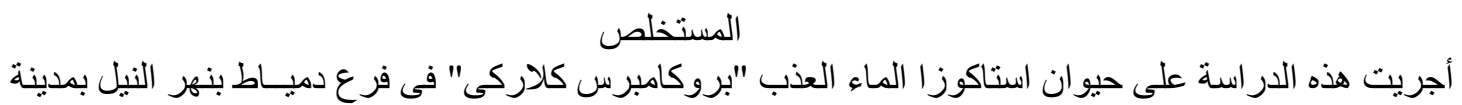

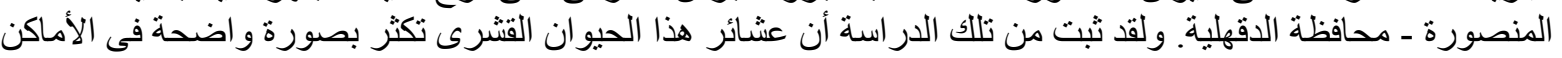

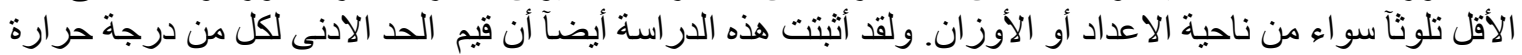

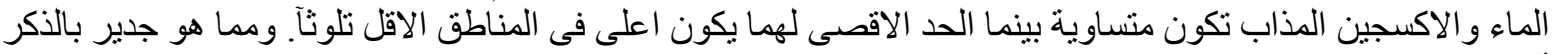

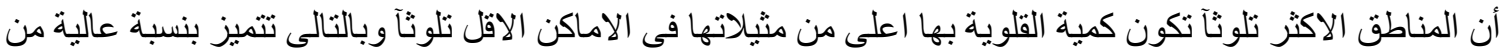

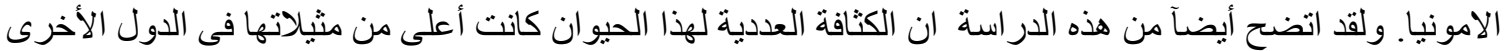

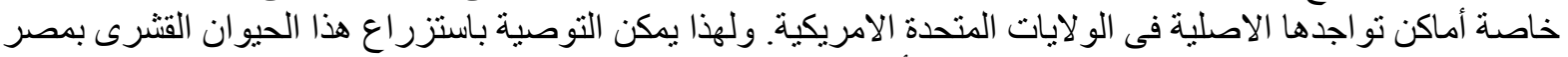

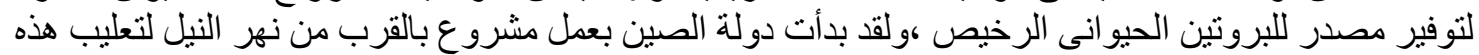

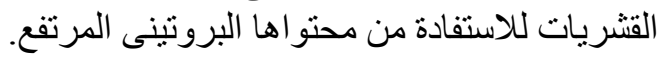


Ecological studies on the freshwater crayfish Procambarus clarkii in the Nile River at El-Mansoura city 